\title{
Increased Attributable Risk Related to a Functional $\mu$-Opioid Receptor Gene Polymorphism in Association with Alcohol Dependence in Central Sweden
}

\author{
Gavin Bart ${ }^{*,}$, Mary Jeanne Kreek ${ }^{1,2}$, Jurg Ott ${ }^{3}, K_{\text {Steven LaForge', Dmitri Proudnikov', Lotta Pollak }}{ }^{\text {and }}$ \\ Markus Heilig ${ }^{2,4}$ \\ 'The Laboratory of the Biology of Addictive Diseases, The Rockefeller University, New York, NY, USA; ${ }^{2}$ Karolinska Institute, Stockholm, Sweden; \\ ${ }^{3}$ The Laboratory of Statistical Genetics, The Rockefeller University, New York, NY, USA; ${ }^{4}$ Laboratory of Clinical Science, NIAAA, NIH, Bethesda \\ MD, USA
}

\begin{abstract}
The $\mu$-opioid receptor (MOR), through its effects on reward and stress-responsivity, modulates alcohol intake in both animal and human laboratory studies. We have previously demonstrated that the frequently occurring AI I8G single-nucleotide polymorphism (SNP) in exon I of the MORgene (OPRM I), which encodes an amino-acid substitution, is functional and receptors encoded by the variant I I8G allele bind the endogenous opioid peptide $\beta$-endorphin with three-fold greater affinity than prototype receptors. Other groups subsequently reported that this variant alters stress-responsivity in normal volunteers and also increases the therapeutic response to naltrexone (a $\mu$-preferring opioid antagonist) in the treatment of alcohol dependence. We compared frequencies of genotypes containing an II8G allele in 389 alcohol-dependent individuals and 170 population-based controls without drug or alcohol abuse or dependence. The AII8G SNP was present in the Hardy-Weinberg equilibrium with an overall frequency of the $118 \mathrm{G}$ allele of $10.9 \%$. There was a significant overall association between genotypes with an II8G allele and alcohol dependence $(p=0.0074)$. The attributable risk for alcohol dependence in subjects with an $118 \mathrm{G}$ allele was $11.1 \%$. There was no difference in AII8G genotype between type I and type 2 alcoholics. In central Sweden, the functional variant I।8G allele in exon I of OPRM I is associated with an increased attributable risk for alcohol dependence.
\end{abstract}

Neuropsychopharmacology (2005) 30, 417-422, advance online publication, 3 November 2004; doi: 10.1038/sj.npp. 1300598

Keywords: alcohol dependence; single-nucleotide polymorphism; opioid system; endogenous; association study; opioid receptor

\section{INTRODUCTION}

Twin registry and adoption studies have shown that the heritability of alcoholism may be as high as $50-60 \%$ (Kendler et al, 1997; Prescott and Kendler, 1999). While early genetic studies of alcoholism focused on archival and phenotypic data (eg Cloninger et al, 1981; Kaij, 1957), recent advances in molecular genetics have permitted a hypothesis-driven evaluation of specific genes, which animal and molecular studies have demonstrated are altered by alcohol. Examples of this latter approach include the study of genes encoding proteins involved in the metabolism of alcohol (eg alcohol dehydrogenase and acetaldehyde dehydrogenase); genes hypothesized to be associated with behaviors linked

*Correspondence: Dr G Bart, The Laboratory of the Biology of Addictive Diseases, The Rockefeller University, 1230 York Avenue, New York, NY I0021, USA, Tel: + 212327 8282, Fax: + 212327 7023, E-mail: bartg@rockefeller.edu

Received 28 June 2004; revised 24 August 2004; accepted 22 September 2004

Online publication: 27 September 2004 at http://www.acnp.org/citations/ Npp092704040298/default.pdf to an increased risk of alcoholism (eg impulsivity and tryptophan hydroxylase); and genes encoding or modulating the transcription of proteins involved in the reinforcing effects of alcohol (eg neurotransmitters).

The endogenous opioid system modulates diverse physiological functions such as stress responsivity, analgesia, cognition, gastrointestinal motility, and immune function (Kreek, 1996). Animal and human studies have shown that alcohol-nondependent offspring with an alcohol-dependent parent show altered responsivity of endogenous opioid mediated systems following alcohol consumption compared to offspring without a family history of alcohol dependence (Gianoulakis et al, 1996; Schuckit et al, 1987). In addition, pharmacological antagonism of $\mu$-opioid receptors (MORs) reduces alcohol consumption in both animal models and human studies (Mason et al, 1994; Ulm et al, 1995; Volpicelli et al, 1992). Quantitative trait locus studies have identified the chromosomal region containing the MOR (OPRM1) gene as important to the development and perpetuation of alcohol consumption (Grisel, 2000). Also, knockout mice lacking OPRM1 do not self-administer alcohol (Hall et al, 2001; Roberts et al, 2000). 
The OPRM1 gene is therefore a logical candidate for genetic association studies of alcoholism. Several singlenucleotide polymorphisms (SNP) have been identified in this gene. Two of these, located within exon 1 (C17T and A118G), are common (ranging from 2 to $48 \%$ across populations), encode amino-acid substitutions, and have been studied by several investigators (Kreek et al, 2004; LaForge et al, 2000). The A118G SNP is of particular interest because, as we originally showed, it is a functional polymorphism resulting in three-fold increased binding affinity of the endogenous opioid $\beta$-endorphin and threefold increased current across $G$ protein-activated inwardly rectifying potassium channels following binding by $\beta$ endorphin (Bond et al, 1998). Subsequently, we hypothesized that one copy of the A118G variant might significantly alter physiological responses mediated by the MOR such as stress response (Bond et al, 1998; Kreek et al, 2004; LaForge et al, 2000). In separate studies, Wand et al (2002) and Hernandez-Avila et al (2003) showed that healthy volunteers with a variant $118 \mathrm{G}$ allele have increased hypothalamic-pituitary-adrenal (HPA) axis response following administration of the $\mu$-preferring opioid antagonist naloxone. As acute alcohol administration and MOR antagonism each stimulate HPA axis activity (eg as measured by peripheral levels of ACTH and cortisol) and this activation is inversely correlated with alcohol craving, the $118 \mathrm{G}$ receptor variant may play an important role in the development or treatment of alcoholism through an HPA axis-mediated mechanism (O’Malley et al, 2002).

Association studies of the A118G polymorphism in the addictive diseases in general, and in alcoholism specifically, are, however, conflicting. Several studies have failed to find an association between either the A118 or the $118 \mathrm{G}$ allele and alcoholism (Bergen et al, 1997; Franke et al, 2001; Gelernter et al, 1999; Hoehe et al, 2000; Kim et al, 2004; Kranzler et al, 1998; Loh et al, 2004; Sander et al, 1998; Schinka et al, 2002), while others have found an association between the A118 allele and alcoholism (Town et al, 1999), and yet others have found that the $118 \mathrm{G}$ allele is associated with alcoholism (Luo et al, 2003). Possible explanations for these conflicting reports include, in some cases, small sample size of the populations under study and, in others, the ethnic heterogeneity of the ascertained populations and admixtures within any single ethnic/cultural group.

We recently reported a significant association between the $118 \mathrm{G}$ allele and heroin addiction in a population from central Sweden with up to $21 \%$ of the attributable risk for developing heroin addiction related to the presence of this polymorphism (Bart et al, 2004). In the present study of alcohol dependence, we again focused on a population from central Sweden in order to reduce the potential effect of population admixture.

\section{METHODS}

\section{Patients and Controls}

A total of 467 alcohol-dependent subjects were recruited from an academic addiction medicine clinic offering medically assisted detoxification and outpatient treatment. Diagnosis of alcohol dependence was determined through completion of the DSM-III-R Checklist by the admitting physician with subsequent verification from patient records by a research nurse. In total, 87 subjects were excluded from the final analysis for the following reasons: incomplete clinical information $(n=17)$, met criteria for dependence on a drug in addition to alcohol $(n=47)$, could not be successfully genotyped $(n=8)$, sample contaminated $(n=1)$, sample not genotyped $(n=14)$. The final alcoholdependent group consisted of 389 subjects (108 female, 281 male), most of whom were also subtyped into type 1 (late onset) and type 2 (early onset) alcoholism using revised criteria (Cloninger et al, 1981; Hallman et al, 1996). Individuals with major psychotic disorders were excluded from the study. Other Axis I and II diagnoses and familial history of alcoholism were not systematically assessed.

The control sample consisted of 170 healthy volunteers (88 female, 82 male) recruited as part of a large populationbased general health survey. Subjects were in good health and did not meet any DSM-III-R SCID-I-defined criteria for any substance-related or psychotic disorder. Familial history of alcoholism was not systematically assessed.

Study subjects were primarily of Swedish ethnicity (Table 1). Subjects from central Sweden were chosen because of the relatively low frequency of population admixture in this region. This area experienced a large Finnish immigration in the 16 th and 17 th centuries. Some Baltic, central European, and southern European (primarily Italian) immigration occurred just before and following World War II. Until around 1970 when more diverse immigrant populations (American, Vietnamese, Iranian, Iraqi) began to arrive, the population of this catchment area had remained stable for several hundred years.

All subjects provided written consent for participation in genetic studies and the protocol was approved by the Stockholm South (patients) and Stockholm North (controls) Human Subjects Ethics Committee.

\section{Genotyping of OPRM1}

Genomic DNA was isolated from peripheral blood lymphocytes. For the control subjects, approximately $100 \mathrm{ng}$ of genomic DNA was amplified by polymerase chain reaction (PCR) using oligonucleotide primers designed to amplify the complete coding region of exon 1 of OPRM1. Sequences of the primers were: $5^{\prime}$-CTC CGC CTG ACG CTC C-3'

Table I Ethnic Distribution

\begin{tabular}{|c|c|c|c|c|c|c|c|c|}
\hline & Swedish & Finnish & Other European & African & Mideastern & Latino & Asian & Unknown/unspecified \\
\hline Alcohol dependent $(n=389)$ & 300 & 72 & 9 & 2 & 0 & I & 0 & 5 \\
\hline Controls $(n=170)$ & 144 & 11 & 12 & I & । & I & 0 & 0 \\
\hline
\end{tabular}

Ethnicity is self-identified. 
(forward) and $5^{\prime}$-GTC CCC CCA GTT TAC CTC C-3' (reverse). A step-down amplification was performed using AmpliTaq Gold (Applied Biosystems, Foster City, CA) in a standard reaction volume of $50 \mu \mathrm{l}$. PCR products were electrophoresed on agarose gel to verify amplification and fragment size. PCR products were then purified and sequenced at The Rockefeller University DNA Sequencing Center using the following sequencing primers: $5^{\prime}$-AAA GGA AGC GGC TGA GGC-3' (forward) and $5^{\prime}$-GTC CCC CCA GTT TAC CTC C-3' (reverse). Genotypes were determined by two independent assessors (GB and KSL) who were blind to the diagnostic data.

Direct analysis of the A118G and C17T polymorphisms was performed in the alcohol-dependent subjects using fluorescent PCR in a TaqMan protocol using TaqMan MGB probes and primers designed according to Applied Biosystems specifications. This technique has been validated against the technique used for sequencing the control subjects.

\section{Statistics}

The overall frequency of each genotype and allele was determined. The odds ratio (OR) was calculated and the Mantel-Haenszel $\chi^{2}$ test was performed to test the null hypothesis of no difference in genotype distribution between opiate-dependent and normal volunteers (Mantel and Haenszel, 1959). For $2 \times 2$ tables with rows corresponding to cases and controls, and columns corresponding to susceptible $v s$ nonsusceptible genotypes, attributable risks were computed (Berry and Armitage, 1994), that is, the estimated proportion of cases in the population who are affected due to the given at-risk genotype(s).

\section{RESULTS}

In all, 389 individuals meeting the DSM-III-R criteria for alcohol dependence and 170 healthy controls with no drug or alcohol abuse or dependence were genotyped for the $\mathrm{C} 17 \mathrm{~T}$ and $\mathrm{A} 118 \mathrm{G}$ polymorphisms in exon 1 of the OPRM1 gene. The mean age (SD; range) of the alcohol-dependent subjects and controls was $55.8(10.1 ; 29-85)$ and 45.6 (15.9; 21-75) years, respectively. Of these, $28 \%$ of the alcoholdependent and $52 \%$ of control subjects were female. Genotype and allele distribution did not vary between genders, so gender stratification was not performed.

Since no subjects with the C17T polymorphism were identified, analysis focused on the A118G polymorphism.
Distribution of the $118 \mathrm{G}$ allele was in the Hardy-Weinberg equilibrium with an overall allelic frequency of $10.9 \%$. Analysis by genotype (autosomal dominant mode of inheritance) revealed significantly greater OR for alcohol dependence in subjects with an $118 \mathrm{G}$ allele $(\mathrm{OR}=1.92$, $\chi_{(1)}^{2}=7.18, p=0.0074$ ) (Table 2). The attributable risk due to genotypes with an $118 \mathrm{G}$ allele was $11.1 \%(95 \% \mathrm{CI}$ $3.6-18.0 \%)$. There was no difference in A118G genotype between type 1 and type 2 alcoholics $\left(\chi_{(1)}^{2}=0.01, p=0.9\right)$ (Table 2).

To minimize concerns about population admixture, a Mantel-Hanszel analysis comparing genotype data between Swedish subjects with two Swedish parents (193 alcohol dependent, 120 control) and all other subjects (196 alcohol dependent, 50 control) showed a significant association between genotypes with an $118 \mathrm{G}$ allele and alcoholism $(p=0.0395)$ (Table 3). Since genotype data for Swedish and non-Swedish individuals were not significantly different, for the above likelihood ratio and attributable risk statistics, the Swedish and non-Swedish subsets were pooled.

\section{DISCUSSION}

Our results support an association of the $118 \mathrm{G}$ allele in exon 1 of the MOR (OPRM1) gene to alcohol dependence, independent of type 1 and type 2 characteristics. In this study population from central Sweden, the attributable risk due to genotypes containing this allele is $11.1 \%$.

Table 2 (a) Genotype Distribution for All Subjects; (b) Genotype Distribution by Cloninger Type I and Type 2 Alcohol Dependence

Alcohol dependent $(n=389) \quad$ Control $(n=170)$

\begin{tabular}{|c|c|c|}
\hline \multicolumn{3}{|l|}{ (a) All subjects ${ }^{a}$} \\
\hline$A|| 8$ & 299 & 147 \\
\hline $\mathrm{A} / \mid 8 \mathrm{G}, \mathrm{G} \| \mathrm{I} \mathrm{G}$ & 90 & 23 \\
\hline \multicolumn{3}{|c|}{ (b) Alcohol-dependent subjects ${ }^{\mathrm{b}}$} \\
\hline & Type I $(n=242)$ & Type $2(n=124)$ \\
\hline Al| 8 & 186 & 96 \\
\hline $\mathrm{A}|| 8 \mathrm{G}, \mathrm{G}|| 8 \mathrm{G}$ & 56 & 28 \\
\hline
\end{tabular}

Table 3 Genotype Distribution in Swedish Subjects with Two Swedish Parents vs All Other Subjects

\begin{tabular}{|c|c|c|c|c|}
\hline & \multicolumn{2}{|c|}{ Swedish with two Swedish parents } & \multicolumn{2}{|c|}{ Not Swedish with non Swedish parents } \\
\hline & Alcohol dependent & Control & Alcohol dependent & Control \\
\hline $\mathrm{A} \mid 18$ & 158 & 104 & $|4|$ & 43 \\
\hline $\mathrm{A}|| 8 \mathrm{G}, \mathrm{G}|| 8 \mathrm{G}$ & 35 & 16 & 55 & 7 \\
\hline
\end{tabular}


The endogenous opioid system is central to the development and persistence of the addictive diseases (Kreek, 1996). The MOR, whose principal endogenous ligand is $\beta$ endorphin, binds opiates as used in the treatment of pain (eg morphine) or abused illicitly (eg heroin and its active metabolites). It is involved in diverse physiological processes including mediation of the stress responsive hypothalamic-pituitary-adrenal (HPA) axis.

While glucocorticoids acting through negative feedback provide the major countermodulatory effect on the HPA axis, the MOR system exerts a secondary form of countermodulation through tonic inhibition (Kreek and Koob, 1998). Alterations in HPA responsivity following acutely and chronically administered opiates, cocaine, and alcohol have been demonstrated in rodent, non-human primate, and human studies (Kreek, 1992; Kreek et al, 2002). Shortacting opioids produce HPA axis suppression through direct effects on MOR, whereas alcohol and cocaine stimulate HPA axis activity through indirect opioidergic effects. Withdrawal from opioids and alcohol both activates the HPA axis and, in the case of opiate withdrawal, increased HPA axis activity precedes, and thus may contribute to the subjective effects of withdrawal (Culpepper-Morgan and Kreek, 1997).

Family history of alcoholism and thus presumably genetic factors may modulate the HPA-axis response to alcohol, but the nature of this modulation is unclear. Both blunted cortisol response (Schuckit et al, 1987) and enhanced ACTH and $\beta$-endorphin response to alcohol have been reported in nondependent offspring of alcoholic subjects (Gianoulakis et al, 1996). More consistently, increased HPA response to the $\mu$-preferring opiate antagonists naloxone or naltrexone has been found in nonalcoholic offspring of alcoholics (King et al, 2002; King et al, 1997; Wand et al, 1998; Wand et al, 2001). Interestingly, naltrexone also attenuated the subjective effects of alcohol in the family history positive social drinkers but not in the family history negative group (King et al, 1997).

It is possible that alcohol is partly consumed for its ability to activate the HPA axis. Following a single priming drink, naltrexone-treated alcohol-dependent subjects drank less alcohol and experienced less craving than did placebotreated subjects. Interestingly, naltrexone stimulated HPA axis to a similar extent as alcohol, and increased levels of plasma cortisol following naltrexone were correlated with decreased craving (O'Malley et al, 2002). While genetics were not part of this study, we hypothesized that the acute alcohol-mimetic effects of increased HPA activation following an opioid antagonist in subjects with the functional A118G SNP may produce a greater reduction in alcohol craving and therefore these subjects may be more responsive to opioid antagonist therapy. This hypothesis has recently received some support by the finding that alcohol-dependent subjects with an $118 \mathrm{G}$ allele return to heavy drinking following treatment with naltrexone later than do similarly treated alcoholics with the prototypic receptor (Oslin et al, 2003).

To date, association studies of alcohol dependence and the A118G SNP have found: (1) a significant association between a haplotype which included the 118G allele and mixed alcohol and opioid dependence (Luo et al, 2003); (2) association between the A118 allele and alcohol dependence
(Town et al, 1999); and (3) no association between the A118G SNP and alcohol dependence (Bergen et al, 1997; Franke et al, 2001; Gelernter et al, 1999; Hoehe et al, 2000; Kranzler et al, 1998; Loh et al, 2004; Sander et al, 1998; Schinka et al, 2002). While Kim et al did not find an association between the A118G SNP and alcohol dependence in a Korean population, they did find that alcoholics homozygous for the $118 \mathrm{G}$ allele drank more days per month than alcoholics with a single $118 \mathrm{G}$ allele who drank more days per month than alcoholics without an 118G allele. Interestingly, there was no difference between genotypes in the amount of alcohol consumed per drinking day (Kim et al, 2004).

The conflicting results of the above studies may be due to differences in ethnicity of the populations under study, since in populations of different ethnic origins the frequency of the $118 \mathrm{G}$ allele can range from less than 2 to 48\% (Bart et al, 2004; Bond et al, 1998; Gelernter et al, 1999; Li et al, 2000; Shi et al, 2002; Szeto et al, 2001; Tan et al, 2003). There may also be nongenetic-mediated environmental factors that contribute to the development of alcohol dependence to a differing extent within and between the ethnic groups previously studied. Here, we controlled for allelic frequency differences in populations by conducting the study in a predominantly Swedish population, which has experienced little admixture over the past several hundred years and remains fairly 'culturally homogeneous'. We also controlled for the type of alcoholism and found no difference in allele distribution between type 1 and type 2 alcoholics. While this control may increase the power of the current study, its generalizability to non-Swedish populations remains uncertain. Further studies replicating the current findings in Swedish and non-Swedish populations are needed.

Studying a population of Swedish heroin addicts, we recently found a significant association between the $118 \mathrm{G}$ allele and heroin addiction, compared to the same population-based control group used in the current study (Bart et al, 2004). In that report, the attributable risk for developing heroin addiction was $21 \%$ when subjects with two Swedish parents were analyzed and $18 \%$ for all subjects. In the present study, the attributable risk was more modest at $11 \%$ overall. This may indicate that the $118 \mathrm{G}$ allele contributes to a common susceptibility for developing addictive disorders, and additionally to the risk of developing opiate addiction. Alternatively, opioid mechanisms may be involved in development of alcohol dependence only in a subgroup of alcoholics, diluting the statistical effect size of the MOR polymorphism.

Surprisingly, we found no subjects with the C17T variant. The allelic frequency of $17 \mathrm{~T}$ has ranged from 0.8 to $21 \%$ across ethnic groups (Berrettini et al, 1997; Bond et al, 1998; Gelernter et al, 1999). A trend ( $p=0.054$ or $p=0.05$ Bond et al and Berrettini et al, respectively) towards a higher frequency of this variant and substance dependence has also been reported (Berrettini et al, 1997; Bond et al, 1998). As this variant, the second most frequently occurring SNP within exon 1 of OPRM1, was not identified, haplotype analysis incorporating this SNP could not be performed. This study may be limited by its focus on exon 1 of OPRM1, in that sequencing of the $5^{\prime}$ region as well as the introns and other exons of this gene would have allowed for haplotype 
analyses. There may be, however, limited utility of haplotype analysis in this association study of the A118G SNP. By demonstrating the functional effect of the A118G SNP in a cellular construct and then in the human laboratory, it appears likely that this SNP is the locus of interest in this study, rather than a nearby coinherited allele. This does not exclude the undoubtedly oligogenetic nature of this complex disease or the need for further identification and study of other SNPs possibly coinherited with the $118 \mathrm{G}$ allele.

In conclusion, the current study found a significant association between genotypes with the $118 \mathrm{G}$ allele of this functional polymorphism in the MOR gene and alcohol dependence in central Sweden.

\section{ACKNOWLEDGEMENTS}

This work was supported in part by National Institutes of Health (NIH)-National Institute on Drug Abuse (NIDA) Research Scientific Award Grant K05-DA00049 (MJK), NIHNIDA Research Grant R01-DA12848 (MJK), NIH-NIDA Research Center Grant P60-DA05130 (MJK), NIH-NIMH Research Grant MH044292 (JO), The Rockefeller University Clinical Scholars Program (GB), Swedish Medical Research Council K2001-21X-10872 (MH), and the SöderströmKönigska Foundation ( $\mathrm{MH})$. We gratefully acknowledge the assistance of Dr Ann Ho.

\section{REFERENCES}

Bart G, Heilig M, LaForge KS, Pollak L, Leal SM, Ott J et al (2004). Substantial attributable risk related to a functional mu-opioid receptor gene polymorphism in association with heroin addiction in central Sweden. Mol Psychiatry 9: 547-549.

Bergen AW, Kokoszka J, Peterson R, Long JC, Virkkunen M, Linnoila $\mathrm{M}$ et al (1997). $\mu$ Opioid receptor gene variants: lack of association with alcohol dependence. Mol Psychiatry 2: 490-494.

Berrettini WH, Hoehe MR, Ferraro TN, DeMaria PA, Gottheil E (1997). Human mu opioid receptor gene polymorphisms and vulnerability to substance abuse. Addict Biol 2: 303-308.

Berry G, Armitage P (1994). Statistical Methods in Medical Research. Blackwell Scientific Publications: Boston.

Bond C, LaForge KS, Tian M, Melia D, Zhang S, Borg L et al (1998). Single-nucleotide polymorphism in the human mu opioid receptor gene alters beta-endorphin binding and activity: possible implications for opiate addiction. Proc Natl Acad Sci USA 95: 9608-9613.

Cloninger CR, Bohman M, Sigvardsson S (1981). Inheritance of alcohol abuse. Arch Gen Psychiatry 38: 861-868.

Culpepper-Morgan JA, Kreek MJ (1997). Hypothalamic-pituitaryadrenal axis hypersensitivity to naloxone in opioid dependence: a case of naloxone-induced withdrawal. Metabolism 46: 130-134.

Franke P, Wang T, Nothen MM, Knapp M, Neidt H, Albrecht S et al (2001). Nonreplication of association between mu-opioidreceptor gene (OPRM1) A118G polymorphism and substance dependence. Am J Med Genet 105: 114-119.

Gelernter J, Kranzler H, Cubells J (1999). Genetics of two mu opioid receptor gene (OPRM1) exon I polymorphisms: population studies, and allele frequencies in alcohol- and drugdependent subjects. Mol Psychiatry 4: 476-483.

Gianoulakis C, Krishnan B, Thavundayil J (1996). Enhanced sensitivity of pituitary beta-endorphin to ethanol in subjects at high risk of alcoholism. Arch Gen Psychiatry 53: 250-257.
Grisel JE (2000). Quantitative trait locus analysis. Alcohol Res Health 24: 169-174.

Hall FS, Sora I, Uhl GR (2001). Ethanol consumption and reward are decreased in $\mu$-opiate receptor knockout mice. Psychopharmacology 154: 43-49.

Hallman J, von Knorring L, Oreland L (1996). Personality disorders according to DSM-III-R and thrombocyte monoamine oxidase activity in type 1 and type 2 alcoholics. J Stud Alcohol 57: $155-161$.

Hernandez-Avila CA, Wand G, Luo X, Gelernter J, Kranzler H (2003). Association between the cortisol response to opioid blockade and the Asn40Asp polymorphism at the $\mu$-opioid receptor locus (OPRM1). Am J Med Genet 118B: 60-65.

Hoehe MR, Köpke K, Wendel B, Rohde K, Flachmeier C, Kidd KK et al (2000). Sequence variability and candidate gene analysis in complex disease: association of $\mu$ opioid receptor gene variation with substance dependence. Hum Mol Genet 9: 2895-2908.

Kaij L (1957). Drinking habits in twins. Acta Genet 7: 437-441.

Kendler KS, Prescott CA, Neale MC, Pedersen NL (1997). Temperance board registration for alcohol abuse in a national sample of Swedish male twins, born 1902 to 1949. Arch Gen Psychiatry 54: 178-184.

Kim SG, Kim CM, Kang DH, Kim YJ, Byun WT, Kim SY et al (2004). Association of functional opioid receptor genotypes with alcohol dependence in Koreans. Alcohol Clin Exp Res 28: 986-990.

King AC, Schluger J, Gunduz M, Borg L, Perret G, Ho A et al (2002). Hypothalamic-pituitary-adrenocortical (HPA) axis response and biotransformation of oral naltrexone: preliminary examination of relationship to family history of alcoholism. Neuropsychopharmacology 26: 778-788.

King AC, Volpicelli JR, Frazer A, O'Brien CP (1997). Effect of naltrexone on subjective alcohol response in subjects at high and low risk for future alcohol dependence. Psychopharmacology (Berl) 129: 15-22.

Kranzler H, Gelernter J, O’Malley S, Hernandez-Avila CA, Kaufman D (1998). Association of alcohol or other drug dependence with alleles of the $\mu$ opioid receptor gene (OPRM1). Alcohol Clin Exp Res 22: 1359-1362.

Kreek MJ (1992). Effects of opiates, opioid antagonists and cocaine on the endogenous opioid system: clinical and laboratory studies. NIDA Res Monogr 119: 44-48.

Kreek MJ (1996). Opioid receptors: some perspectives from early studies of their role in normal physiology, stress responsivity, and in specific addictive diseases. Neurochem Res 21: $1469-1488$.

Kreek MJ, Koob GF (1998). Drug dependence: stress and dysregulation of brain reward pathways. Drug Alcohol Depend 51: 23-47.

Kreek MJ, LaForge KS, Butelman E (2002). Pharmacotherapy of addictions. Nat Rev Drug Disc 1: 710-726.

Kreek MJ, Nielsen DA, LaForge KS (2004). Genes associated with addiction: alcoholism, opiate, and cocaine addiction. Neuro Mol Med 5: 85-108.

LaForge KS, Yuferov V, Kreek MJ (2000). Opioid receptor and peptide gene polymorphisms: potential implications for addictions. Eur J Pharmacol 410: 249-268.

Li T, Liu X, Zhu ZH, Zhao J, Hu X, Sham PC et al (2000). Association analysis of polymorphisms in the $\mu$ opioid gene and heroin abuse in Chinese subjects. Addict Biol 5: 181-186.

Loh EW, Fann CSJ, Chang YT, Chang CJ, Cheng ATA (2004). Endogenous opioid receptor genes and alcohol dependence among Taiwanese Han. Alcohol Clin Exp Res 28: 15-19.

Luo X, Kranzler HR, Zhao H, Gelernter J (2003). Haplotypes at the OPRM1 locus are associated with susceptibility to substance dependence in European-Americans. Am J Med Genet 120B: 97-108. 
Mantel N, Haenszel W (1959). Statistical aspects of analysis of data from retrospective studies of disease. J Natl Cancer Inst 22: 719-748.

Mason BJ, Ritvo EC, Morgan RO, Salvato FR, Goldberg G, Welch B et al (1994). A double-blind, placebo-controlled pilot study to evaluate the efficacy and safety of oral nalmefene $\mathrm{HCl}$ for alcohol dependence. Alcohol Clin Exp Res 18: 1162-1167.

O’Malley SS, Krishnan-Sarin S, Farren C, Sinha R, Kreek MJ (2002). Naltrexone decreases craving and alcohol self-administration in alcohol-dependent subjects and activates the hypothalamopituitary-adrenocortical axis. Psychopharmacology 160: 19-29.

Oslin DW, Berrettini WH, Kranzler H, Pettinati H, Gelernter J, Volpicelli JR et al (2003). A functional polymorphism of the muopioid receptor gene is associated with naltrexone response in alcohol dependent patients. Neuropsychopharmacology 28: 1546-1552.

Prescott CA, Kendler KS (1999). Genetic and environmental contributions to alcohol abuse and dependence in a population-based sample of male twins. Am J Psychiatry 156: 34-40.

Roberts AJ, McDonald JS, Heyser CJ, Kieffer BL, Matthes HWD, Koob GF et al (2000). $\mu$ Opioid receptor knockout mice do not self-administer alcohol. J Pharmacol Exp Ther 293: 1002-1008.

Sander T, Gscheidel N, Wendel B, Samochowiec J, Smolka M, Rommelspacher $\mathrm{H}$ et al (1998). Human mu-opioid receptor variation and alcohol dependence. Alcohol Clin Exp Res 22: 2108-2110.

Schinka J, Town T, Abdullah L, Crawford F, Ordorica PI, Francis E et al (2002). A functional polymorphism within the $\mu$-opioid receptor gene and risk for abuse of alcohol and other substances. Mol Psychiatry 7: 224-228.

Schuckit MA, Gold E, Risch C (1987). Plasma cortisol levels following ethanol in sons of alcoholics and controls. Arch Gen Psychiatry 44: 942-945.
Shi J, Hui J, Xu Y, Wang F, Huang W, Hu W (2002). Sequence variations in the mu-opioid receptor gene (OPRM1) associated with human addiction to heroin. Hum Mutat 19: 459-460.

Szeto CY, Tang NL, Lee DT, Stadlin A (2001). Association between $\mathrm{mu}$ opioid receptor gene polymorphisms and Chinese heroin addicts. NeuroReport 12: 1103-1106.

Tan E, Tan C, Karupathivan U, Yap EPH (2003). Mu opioid receptor gene polymorphisms and heroin dependence in Asian populations. NeuroReport 14: 569-572.

Town T, Abdullah L, Crawford F, Schinka J, Ordorica PI, Francis E et al (1999). Association of a functional mu-opioid receptor allele (+118A) with alcohol dependency. Am J Med Genet 88: 458-461.

Ulm RR, Volpicelli JR, Volpicelli LA (1995). Opiates and alcohol self-administration in animals. J Clin Psychiatry 56: 5-14.

Volpicelli JR, Alterman AI, Hayashida M, O'Brien CP (1992). Naltrexone in the treatment of alcohol dependence. Arch Gen Psychiatry 49: 876-880.

Wand G, McCaul ME, Gotjen D, Reynolds J, Lee S (2001). Confirmation that offspring from families with alcohol-dependent individuals have greater hypothalamic-pituitary-adrenal axis activation induced by naloxone compared with offspring without a family history of alcohol dependence. Alcohol Clin Exp Res 25: 1134-1139.

Wand GS, Mangold D, El Deiry S, McCaul ME, Hoover D (1998). Family history of alcoholism and hypothalamic opioidergic activity. Arch Gen Psychiatry 55: 1114-1119.

Wand GS, McCaul M, Yang X, Reynolds J, Gotjen D, Lee S et al (2002). The mu-opioid receptor gene polymorphism (A118G) alters HPA axis activation induced by opioid receptor blockade. Neuropsychopharmacology 26: 106-114. 